\title{
Susceptibility Status of Aedes aegypti Mosquito (Diptera: Culicidae) to Organophosphate and Pyrethroid Insecticides in Tanjung Priok Port Health Quarantine
}

\section{Status Kerentanan Nyamuk Aedes aegypti (Diptera: Culicidae) terhadap Insektisida Organofosfat dan Piretroid di Kantor Kesehatan Pelabuhan Tanjung Priok}

\author{
Yahiddin Seliandro $^{1}$, Sitti Rahmah Umniyati ${ }^{2}$, Tri Baskoro T. Satoto ${ }^{2}$, Nur Alvira Pascawati ${ }^{3 *}$ \\ ${ }^{1}$ Sub-Direktorat Pencegahan dan Pengendalian Penyakit Tular Vektor dan Zoonotik, Kementerian \\ Kesehatan \\ Jalan Percetakan Negara No.29, Johar Baru, Kota Jakarta Pusat, Daerah Khusus Ibukota Jakarta, \\ Indonesia \\ ${ }^{2}$ Parasitologi, FKKMK Universitas Gadjah Mada \\ Jalan Farmako Sekip Utara, Daerah Istimewa Yogyakarta, Indonesia \\ ${ }^{3}$ Epidemiologi, Fakultas Ilmu Kesehatan, Universitas Respati Yogyakarta \\ Jalan Laksda Adisucipto KM 6,3, Depok, Sleman, Daerah Istimewa Yogyakarta, Indonesia \\ *E_mail: irha011185@yahoo.com
}

\begin{abstract}
ABSTRAK
Penanggulangan penyakit tular hewan dan vektor di wilayah kesehatan pelabuhan harus dilakukan secara cepat dan tepat. Salah satu tindakan yang dilakukan adalah pengendalian nyamuk Ae. aegypti menggunakan insektisida. Penelitian ini dilakukan untuk mengetahui dan mengevaluasi status kerentanan insektisida golongan organofosfat dan piretroid, peningkatan aktifitas enzim esterase non spesifik dan mutasi gen voltage-gated sodium channel (VGSC) pada nyamuk Ae. aegypti di area kerja Karantina Kantor Kesehatan Pelabuhan Tanjung Priok tahun 2016. Status kerentanan insektisida golongan organofosfat dan piretroid ditentukan oleh tiga metode uji yang berbeda: metode bioassay (kertas impregnasi yang mengandung 0,8\% malathion, sipermetrin 0,05\% dan temephos 0,02 ppm). Metode biokimia dan uji biomolekuler (PCR dan sequencing) untuk mengetahui mutasi gen VGSC. Pengujian bioassay menggunakan insektisida malathion, sipermetrin dan temephos menunjukan bahwa Ae. aegypti yang berasal dari pelabuhan Tanjung Priok, Sunda Kelapa, dan Muara Angke telah resisten terhadap malathion dan sipermetrin, sedangkan larva Ae. aegypti masih rentan terhadap temephos. Hasil pengujian biokimia pada nyamuk Ae. aegypti terhadap organofosfat menunjukkan tingkat resistensi sedang dan sensitif. Mutasi gen VGSC terjadi pada site S989P dan V1016G, sedangkan pada site F1534 belum menunjukkan adanya mutasi.
\end{abstract}

Kata kunci: Ae. aegypti, malathion, temephos, cypermethrin, voltage-gated sodium channel

\begin{abstract}
Animal-borne diseases and vectors in seaport health areas is designated to be done in a rapid and precise manner. One of the Ae. aegypti control is using insecticides. The aims of this study are to find out and evaluate the susceptibility status of Ae. aegypti to organophosphate and pyrethroid insecticides, and also to observe the increase of non-specific esterase enzyme activities and voltage-gated sodium channel (VGSC) gene mutation in Ae. aegypti mosquitoes in Tanjung Priok Port Health Quarantine working area in 2016. Susceptibility status is determined by three distinct test methods: bioassay method (Impregnated paper containing 0.8\% malathion, $0.05 \%$ cypermethrin and $0.02 \mathrm{ppm}$ temephos). Biochemistry method and biomolecular assay (PCR and sequencing) to identify VGSC gene mutation. Based on bioassay test using malathion, cypermethrin and temephos showed that Ae. aegypti mosquitoes from Tanjung Priok, Sunda Kelapa, and Muara Angke ports has been resistance to malathion and cypermethrin, and were still susceptible to temephos. The results of biochemical tests on Ae aegypti to organophosphates showed moderate levels of resistance and sensitivity. VGSC gene mutation was observed on sites S989P and V1016G, while site F1534 did not showed any mutation.
\end{abstract}

Keywords: Ae. aegypti, malathion, temephos, cypermethrin, voltage-gated sodium channel

\section{INTRODUCTION}

Vector borne disease remains a health problem in Indonesia. Extend of vector borne diseases occurs not only locally but also occur in cross-regional and cross-country. ${ }^{1}$ Advances in transportation technology may play a role in 
the spread of diseases from one region to another and even to other countries. The spread occurred dominantly through the entrance of transportation processes, such as seaports and airports. The Ministry of Health is responsible for the 2005 International Health Regulations (IHR) and the General Directorate of Disease Prevention and Environmental Health may act as the operator and Technical Implementation Unit by the Port Health Quarantines. $^{2}$

The function of Port Health Quarantine (PHQ) is to prevent the entry of quarantine diseases and infectious diseases potentially causing outbreaks. ${ }^{3}$ Class I Port Health Quarantine of Tanjung Priok is one of 56 PHQs in Indonesia, which consists of one center (Tanjung Priok) and five working areas (Muara Baru, Kali Baru, Marunda, Sunda Kelapa and Muara Angke). Environmental risk factor control section is in charge of vector control division controlling the vectors and other unsettling animals in the working area.

Vector control targets are the larvae and adult mosquitoes of Aedes aegypti. Vector control could be done in several ways, namely chemical, biological, physical and integrated vector control. ${ }^{4}$ Chemical vector control has been selected by the officers of PHQ as the main option in the eradication of vectors such as mosquitoes, cockroaches, rats and fleas in both seaport and airport.

Chemical vector control using insecticides (mosquitoes and larvae) continuously may trigger resistance due to the ability of Ae. aegypti to further develop body's immune system against commonly used insecticides. ${ }^{1}$ Prolonged and frequent use of insecticides can lead to decreased vulnerability of the mosquitoes, making alternate use of insecticide active ingredients necessary. ${ }^{5}$ The application of insecticides for vector control will only useful when used in appropriate circumstances. ${ }^{6}$

Aedes aegypti mosquitoes in Puerto Rico have been resistant to organophosphate and several other insecticides. ${ }^{7}$ In Indonesia the susceptibility of Aedes aegypti to malathion in several cities such as Bandung, Jakarta, Surabaya and Palu are still classified as vulnerable, but in Palembang is considered resistant. ${ }^{8}$ The determination of resistance mechanism of mosquitoes is carried out using biochemical and biomolecular assays. Biochemical test is done to detect mosquito resistance based on the quantification of the enzyme responsible in the resistance process. Increased activities of non-specific esterase enzyme are closely related to the biochemical resistance mechanisms. ${ }^{8}$ Biochemical tests to determine the activity of esterase enzymes can identify the mechanism that causes insect resistance to malathion insecticides. ${ }^{9}$ Resistance to malathion has been reported in several locations such as research in French Guiana in 2003. ${ }^{10}$ Resistance to malathion in the population of Aedes aegypti mosquitoes in several other districts in Central Java such as Semarang, Purbalingga, Kendal and Grobogan was reported by Sunaryo in $2014 .{ }^{11}$ The same report was reported by Widiastuti and Ikawati in 2016 that resistance to malathion had occurred in the Ae. aegypti mosquito population in Pekalongan. ${ }^{12}$

The basic principle of resistance detection in vector is the molecular basis to conventionally identify genes being targeted by insecticides, for example the voltage-gated sodium channel (VGSC). VGSC gene mutation is the primary mechanism of insect resistance to DDT and pyrethroids. ${ }^{13}$ Several VGSC gene mutations occurrence have been reported in agricultural insects and health insects.

VGSC gene mutations in Ae. aegypti has been detected in nine different loci. ${ }^{14}$ The amino acid changes in Ae. aegypti mosquitoes most frequently observed at the points S989, I1011, L1014 and V1016, which are all located in segment 6 of domain II. Current identification done indicates that the amino acid replacement in F1534 is located in the segment 6 of domain III. ${ }^{15}$

The aims of this research are to determine susceptibility status to organophosphate and pyrethroid insecticides, 
as well as to rule out increased activities of non-specific esterase enzyme and voltagegated sodium channel (VGSC) gene mutation in Ae. aegypti mosquitoes in Tanjung Priok Port Health Quarantine working area.

\section{METHODS}

The research applies a descriptive analytic study. Samples used were Ae. aegypti mosquitoes collected from three distinct locations: Tanjung Priok, Sunda Kelapa and Muara Angke port work area using ovitrap. The number of ovitrap installed in each region according to what was determined by FUNASA (Fundaco National de Saude) cit Lima namely the number of houses $<60,000$ using 100 ovitrap, ${ }^{16}$ which are installed as many as 2 pieces in each house namely indoor and outdoor. The testing was done in 3 separate techniques: bioassay (susceptibility test) using WHO standard. ${ }^{17}$ Methods produced by the University of Science Malaysia (USM) Penang with impregnated paper $(0.8 \%$ malathion and $0.05 \%$ cypermethrin). Female Ae. aegypti mosquitoes used are F1 colonization (reared in the laboratory until it becomes a mosquito and lay eggs) in fully glucose-fed condition and 3-5 days old. Total number of test tubes was 5 tubes: 4 exposure tubes and 1 control tube use clean white paper/HVS paper. Positive control using mosquito larvae Laboratory of Parasitology, Faculty of Medicine, UGM. Twenty-five mosquitoes were put in a redmarked test tube and were exposed to insecticides $(0.8 \%$ malathion and $0.05 \%$ cypermethrin) for one hour, then the mosquitoes were transferred into the greenmarked holding tube. At the end of recovery period ( 24 hours post-exposure), the number of dead mosquitoes was counted and recorded.

Determination of resistance status based on the results of biochemical tests using the Lee method ${ }^{18}$ and using bioassays with WHO standards: ${ }^{9}$

1. Vulnerable/sensitive is the state of the Ae. aegypti mosquito based on biochemical tests measured qualitatively if the score
$<2.0$ (colorless), while quantitatively with absorbance value (AV) reading using a spectrophotometer, this vulnerable condition is indicated by the AV value <negative control mean $+3 \mathrm{SD}$, vulnerable (SS ) Whereas the death bioassay is 99$100 \%$;

2. Moderate tolerance/resistance is the condition of Ae. aegypti mosquitoes based on biochemical tests that are measured qualitatively when the score is 2.0-2.5 (blue), while quantitatively with absorbance value (AV) readings using a spectrophotometer, this vulnerable condition is indicated by negative control score $+3 \mathrm{SD} \leq \mathrm{AV} \leq$ positive, tolerant (RS) control score. Whereas the death bioassay is 99-100\%.

3. High resistance/resistance is the condition of Ae. aegypti mosquitoes based on biochemical tests that are measured qualitatively if the score is $>2.5$ (dark blue), while quantitatively with absorbance value (AV) readings using a spectrophotometer, this resistance condition is indicated by the $\mathrm{AV}$ value > average positive control, resistant (RT). Whereas in bioassays using WHO standards of death $<80 \%$.

One milliliter of temephos, concentration of $156.25 \mathrm{mg} / \mathrm{l}$, was pipetted and $249 \mathrm{ml}$ of water was added to obtain a concentration of $0.625 \mathrm{ml} / \mathrm{l}$. Cups were labeled for both treatment and control. Treatment cup was filled with $242 \mathrm{ml}$ of water and $8 \mathrm{ml}$ of temephos concentration of $0.625 \mathrm{ml} / 1$ was added, while control cup was filled with 250 $\mathrm{ml}$ of water. Twenty-five larvae were inserted in each cup. Observation was carried out by recording the number of dead larvae 24 hours post-exposure.

Biochemical test to measure nonspecific esterase enzyme activity was conducted using the Lee method. Third and fourth instar larvae of Ae. aegypti were homogenized in $0.5 \mathrm{ml}$ of $0.02 \mathrm{M}$ Phosphate Buffer Saline (PBS) solution at $\mathrm{pH}$ 7.0. Fifty milliliters of the solution was pipetted and transferred into micro plate wells. Substrates of 
$\alpha$-naphthyl acetate and acetone $(6 \mathrm{~g} / \mathrm{l})$ in $50 \mathrm{ml}$ phosphate buffer $(0.02 \mathrm{M}, \mathrm{pH} 7.0)$ were added to $50 \mathrm{ml}$ micro plate and was let stand for 60 seconds. Fifty milliliters of coupling reagents composed of $150 \mathrm{mg}$ Fastbluesalt B (tetrazotized o-dianisidine, Sigma) in $15 \mathrm{ml}$ of distilled water and $35 \mathrm{ml}$ of 5\% SDS (sodium dodecyl sulphate) was pipetted into each microplate well. The reaction lasted for 10 minutes, the initially appeared red color changed gradually into blue color. Measurement of the enzyme activity was determined qualitatively (change in color intensity) and quantitatively using a Spectrophotometer at wave length $\lambda=450 n^{5}$.

The biomolecular testing to detect VGSC gene mutations had been conducted using conventional method. Samples of mosquitoes used in the PCR derived from Tanjung Priok Port. DNA isolation was done Insta Gene Matrix Kit (Cat \#732-6030 BIO RAD). Mosquitoes were crushed using teflon pestle and were put in Eppendorf tubes. About $100 \mu 1$ of PBS solution was added into Eppendorf tube and followed by centrifugation at a speed of $12000 \mathrm{~g}$ for 1 minute, the supernatant was later discarded. As much as $100 \mu \mathrm{l}$ of InstaGene Matrix was added and be incubated at $56^{\circ} \mathrm{C}$ for 45 minutes using water bath. The solution was then homogenized using high-velocity vortex for 10 seconds and was transferred to a water bath at a temperature of $100^{\circ} \mathrm{C}$ for 8 minutes, followed by another high-velocity vortex for 10 seconds. The solution was centrifuged at a speed of $12000 \mathrm{~g}$ for 1 minute and was stored at $-20^{\circ} \mathrm{C}$.

Amplification by PCR using first primers of AaSCF1 (CAA AGA TGT GGA TCG CTT CC) and AaSCR4 (GGA CTG CGC GCT AAT TGT TA) detected point mutations in the targets of S989P and V1016G. Primer I amplification is done using PCR in $25 \mu 1$ reaction volume consisting of $12.5 \mu \mathrm{l}$ of PCR Mix, $1 \mu 1$ of forward primer, $1 \mu 1$ of reverse primer, $8.5 \mu \mathrm{l}$ of $\mathrm{ddH} 2 \mathrm{O}$ and $2 \mu \mathrm{l}$ of DNA template. Amplification stage was begun with pre-denaturation stage at $94^{\circ} \mathrm{C}$ for 3 minutes, 35 cycles of amplification (denaturation at $94^{\circ} \mathrm{C}$ for 15 seconds, annealing at $57^{\circ} \mathrm{C}$ for 30 seconds, elongation at $72^{\circ} \mathrm{C}$ for 30 seconds) and final elongation at a temperature of $72^{\circ} \mathrm{C}$ for 10 minutes.

Second primers of AaSCF7 (GAG AAC AAC ATG CCG TCG TT) and AaSCR7 (GAC GAC GAA GAA CAG ATC GT) detected point mutations in the target of F1534. Primers II amplification was conducted in $25 \mu \mathrm{l}$ reaction volume consisting of $12.5 \mu \mathrm{l}$ of PCR Mix, $1 \mu 1$ of forward primer, $1 \mu 1$ of reverse primer, $8.5 \mu \mathrm{l}$ of $\mathrm{ddH} 2 \mathrm{O}$ and $2 \mu 1$ of DNA templates with pre-denaturation stage at $94^{\circ} \mathrm{C}$ for 3 minutes, 40 amplification cycles (denaturation at $94^{\circ} \mathrm{C}$ for 15 seconds, annealing at $59^{\circ} \mathrm{C}$ for 30 seconds, elongation at $72^{\circ} \mathrm{C}$ for 30 seconds) and final elongation at a temperature of $72^{\circ} \mathrm{C}$ for 10 minutes. Electrophoresis was performed using $2 \%$ arose and followed by examination under ultraviolet light.

Results of biochemical tests were done both qualitatively and quantitatively. PCR products were sequenced and sent to Science Genetics with 2 samples on each PCR product. VGSC gene mutation testing was done qualitatively by PCR results and sequencing analysis was carried out using Mega Program version 6.0.

\section{RESULTS}

Ovitrap installation was done to collect mosquito eggs of throughout the research area. Installation was done in houses, public buildings and offices in Tanjung Priok, Sunda Kelapa and Muara Angke port. Obtained results after the installation of 100 ovitrap were as follows: Sunda Kelapa port has the highest percentage with eggs-positive ovitrap at 34\%, while the Tanjung Priok port gained as much as $21 \%$ and Muara Angke port attained as much as $20 \%$.

Bioassay results of Ae. aegypti were performed against malathion, temephos (organophosphates) and cypermethrin (pyrethroids). Ae. aegypti mosquitoes in three ports have been showed resistance to $0.8 \%$ malathion and $0.05 \%$ cypermethrin with the 
highest mortality at $5 \%$, whereas $0.02 \mathrm{ppm}$

with mortality at $100 \%$ (Table 1).

temephos was still classified as susceptible

Table 1. Percentage of Ae. aegypti Mosquito Mortality and Bioassay Results Against 0.8\% Malathion, $0.05 \%$ Cypermethrin and 002 ppm Temephos in TanjungPriok Port Health Quarantine

\begin{tabular}{|c|c|c|c|c|c|c|}
\hline \multirow{3}{*}{ Origin of Samples } & \multicolumn{6}{|c|}{ Insecticides } \\
\hline & \multicolumn{2}{|c|}{ Malathion } & \multicolumn{2}{|c|}{ Cypermethrin } & \multicolumn{2}{|c|}{ Temephos } \\
\hline & Mortality (\%) & Status & Mortality (\%) & Status & Mortality (\%) & Status \\
\hline Tanjung Priok port & 2 & Resistant & 0 & $\underset{\mathrm{t}}{\text { Resistan }}$ & 100 & Susceptible \\
\hline Sunda Kelapa port & 3 & Resistant & 3 & $\begin{array}{c}\text { Resistan } \\
\mathrm{t}\end{array}$ & 99 & Susceptible \\
\hline Muara Angke port & 2 & Resistant & 5 & $\underset{t}{\text { Resistan }}$ & 100 & Susceptible \\
\hline Control & 0 & - & 0 & - & 0 & - \\
\hline
\end{tabular}

Biochemical testing on non-specific esterase enzyme activity against organophosphates was conducted using the determination of positive cut-off point for Spectrophotometer readings by calculating average value of susceptible $\mathrm{AV}+3 \mathrm{SD}$, namely $0.242+3(0.040)=0.363$. Based on these calculations, Ae. aegypti mosquitoes originated from the three study ports may be classified as susceptible (SS) if the AV value $<0.363$, tolerance value (SR) was obtained from AV values 0.363 to 0.587 , while the level of severe resistance (RR) is categorized if the $\mathrm{AV}$ value $>0.587$.

From the total of 48 samples, Ae. aegypti mosquitoes in Tanjung Priok port, 24 were found sensitive and 24 showed moderate resistance, whereas in the port of Sunda Kelapa, 41 were found sensitive and 7 showed moderate resistance, 39 were found sensitive and 9 showed moderate resistance in Muara Angke port (Table 2). Qualitative observations (color intensity score) revealed Ae. aegypti population from the ports of Tanjung Priok, Sunda Kelapa and Muara Angke have not yet been classified as resistant as shown in Table 2. The highest tolerance percentage of Ae. aegypti population showed in TanjungPriok port at $58 \%$, while in two other ports at $25 \%$ (Sunda Kelapa port) and at 17\% (Muara Angke port).

Table 2. $\quad$ Illustration of Susceptibility Status of Ae. aegypti Larvae Originated from Three Distinct Tanjung Priok Port Health Quarantine using Biochemical Testing (Non-Specific Esterase Enzyme Activity against $\alpha$-Naphthyl Acetate Substrate)

\begin{tabular}{lcccccc}
\hline & \multicolumn{3}{c}{ Qualitative } & \multicolumn{3}{c}{ Quantitative } \\
\cline { 2 - 7 } Origin of Samples & Sensitive & Moderate & High & Susceptible & Tolerant & Resistant \\
\cline { 2 - 7 } & & Resistance & Resistance & AV<2.0 & AV 2.0-2.5 & AV>2.50 \\
\hline Tanjung Priok port & 24 & 24 & 0 & $42 \%$ & $58 \%$ & 0 \\
Sunda Kelapa port & 41 & 7 & 0 & $75 \%$ & $25 \%$ & 0 \\
Muara Angke port & 39 & 9 & 0 & $83 \%$ & $17 \%$ & 0 \\
\hline
\end{tabular}


Biomolecular VGSC gene mutation testing was performed using PCR from isolated adult Ae. aegypti mosquitoes and later be continued with sequencing. Primers used consist of two primers. The first primers coded as AaSCF1 and AaSCR4, of which the PCR results then be electrophoresed on $2 \%$ agarose gel and observations performed under ultraviolet transilluminator, revealed specific band with the size of 619 bp (Figure 1). Primers AaSCF1 and AaSCR4 were used to detect VGSC gene mutations at amino acid sites of 989 and 1016.

The second primers coded AaSCF7 and AaSCR7, of which the PCR results then be electrophorized on 2\% agarose gel and observations performed under ultraviolet transilluminator, showed specific band with the size of 748 bp (Figure 2).

VGSC DNA fragments as amplification products using AaSCF1 and AaSCR4 primers were visualized using 2\% agarose gel electrophoresis (Figure 1).

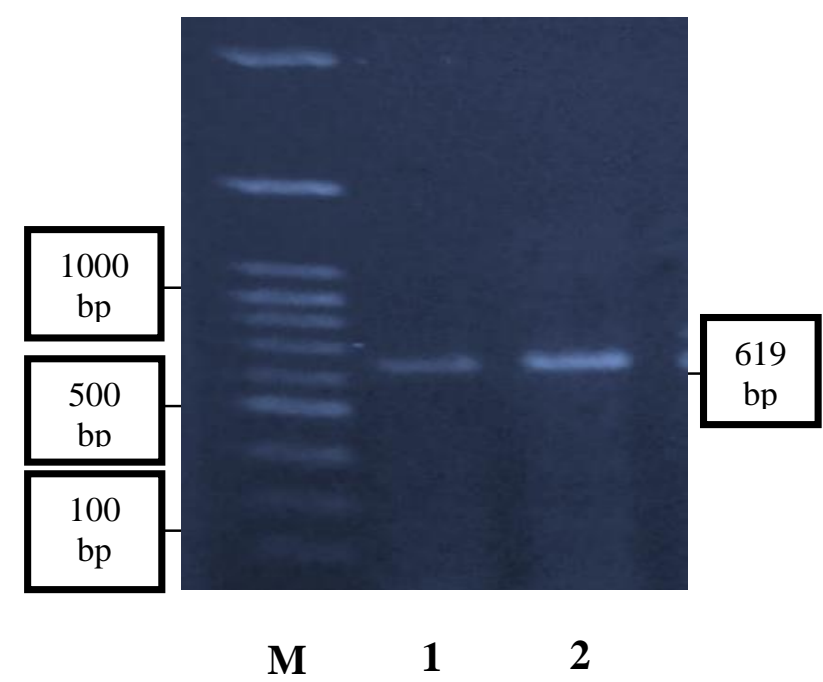

Figure 1. Visualization of VGSC Amplification Products using AaSCF1 and AaSCR4 Primers. [M]: DNA marker; [1,2]: Ae. aegypti DNA obtained from populations in Tanjung Priok Port Health Quarantine working area, product of PCR 619 bp
VGSC DNA fragments as amplification products using AaSCF7 and AaSCR7 primers were visualized using 2\% agarose gel electrophoresis (Figure 2).

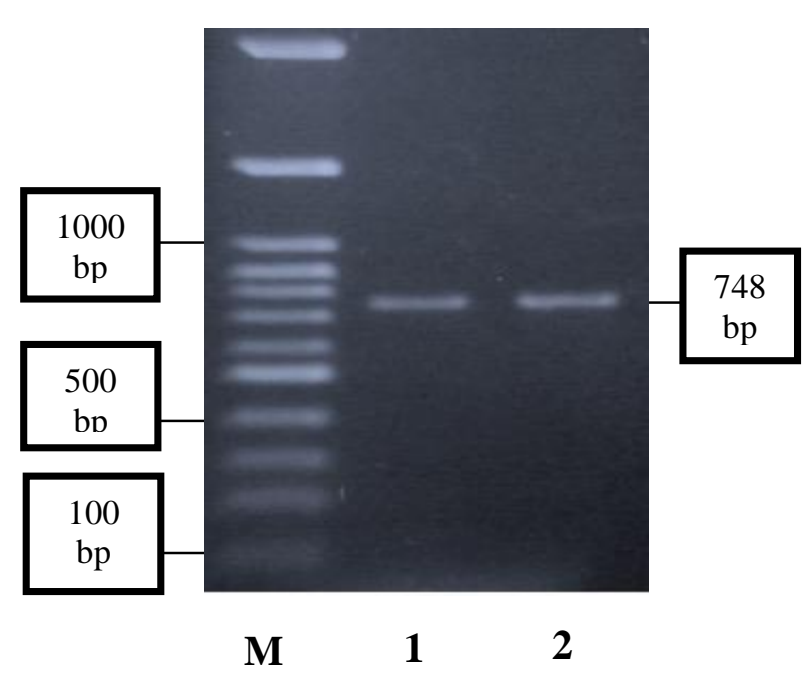

Figure 2. Visualization of VGSC Amplification Products using AaSCF7 and AaSCR7 Primers. [M]: DNA marker; [1,2]: Ae. aegypti DNA obtained from populations in TanjungPriok Port Health Quarantine working area, product of PCR $748 \mathrm{bp}$

Aedes aegypti VGSC gene sequencing results with primers of AaSCF1 and AaSCR4 performed with alignment using Gen Bank (Accession No AB914689 and AB914690) showed nucleotide changes from TCC into CCC and GTA becomes GGA (Figure 3). Aedes aegypti VGSC gene sequencing results with primers of AaSCF7 and AaSCR7 performed with alignment using Gen Bank (Accession No AB914687 and AB914688) showed no changes in the nucleotide TTC (Figure 4).

Sequencing results were analyzed using Mega Program version 6.0 to identify VGSC gene mutation at the target point mutation. Sequencing analysis results of amplification product DNA fragments using primers of AaSCF1 and AaSCR4 are illustrated in Figure 3. The major changes observed in nucleotides TCC into CCC (S989P) and GTA becomes GGA (V1016G). 


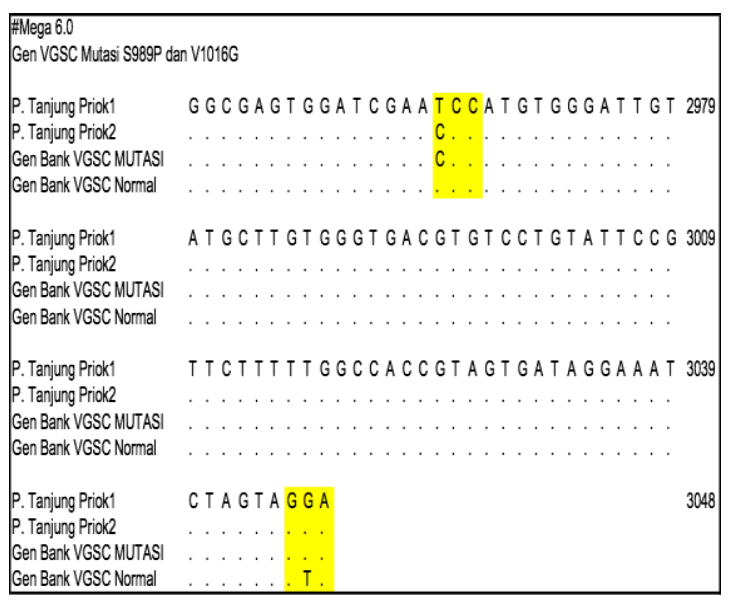

Figure 3. Sequencing Analysis Results from Mosquito Samples in TanjungPriok Port (Primers of AaSCF1 and AaSCR4), Ae. aegypti VGSC Gene and Alignment Using Gen Bank

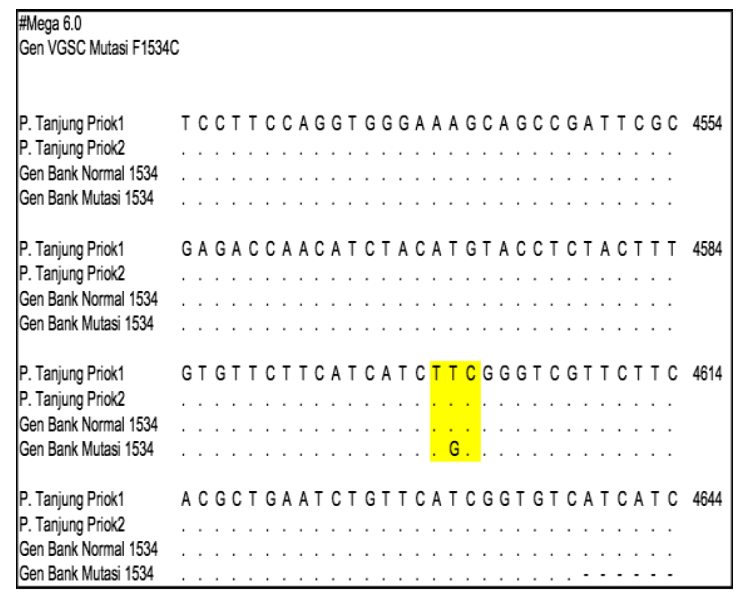

Figure 4. Sequencing Analysis Results from Mosquito Samples in Tanjung Priok Port (Primers of AaSCF7 and AaSCR7), Ae. aegypti VGSC Gene and Alignment using Gen Bank

\section{DISCUSSION}

Bioassay results in three working areas of Tanjung Priok Port Health Quarantine (Tanjung Priok, Muara Angke and Sunda Kelapa port) showed resistance to $0.8 \%$ malathion and $0.05 \%$ cypermethrin. Nevertheless, several cities in Indonesia are still susceptible to malathion. Malathion resistance has occurred in Palu and Yogyakarta. ${ }^{19}$ The results of Soenjono's research in Tomohon City showed that all tested mosquito samples were resistant to $0.8 \%$ malathion, ${ }^{20}$ however some areas in Central Java are still susceptible. ${ }^{21}$

Contrasting state happened in the research results in three ports, of which the outcome showed susceptible status to insecticide temephos. The mortality rate was quite high, ranging from $99 \%$ to $100 \%$. Resistance occurring in Tanjung Priok Port Health Quarantine working area may allow cross-resistance of malathion and cypermethrin. Cross-resistance possibly occur in mosquitoes controlling factors that potentially against transmission of Dengue Hemorrhagic Fever at State Elementary 1 Schools in Yogyakarta, where the individual mosquito developed resistance to two or more insecticides, ${ }^{21}$ while in multiple resistance the individual mosquito may have two or more mechanisms of resistance. ${ }^{14}$

Mechanism of insect resistance to insecticides may cause by the following events: 1) increased insecticide detoxification (becomes non-toxic) due to the action of certain enzymes; 2) decreased insecticide target site sensitivity in insects; 3 ) a decrease in the rate of insecticide penetration through the skin leading to insecticide resistance. ${ }^{22}$

In three working areas of Tanjung Priok Port Health Quarantine, biochemical test results on Ae. aegypti mosquitoes shows a wide range of $\mathrm{AV}$ value, ranging from 0.147 to 0.544 . Higher enzyme activity has been observed in Tanjung Priok Port, unlike in Sunda Kelapa and Muara Angke Port. Difference in susceptibility status through increased non-specific esterase enzyme activity in the three ports is associated with higher frequency of insecticide use discovered in Tanjung Priok Port, compared to in Sunda Kelapa and Muara Angke Port. Study on Ae. aegypti mosquitoes showed resistance tendency to organophosphates in broad scale. Increased non-specific esterase enzyme activity has been reported in Cimahi, Yogyakarta and Jakarta, while in Bogor and Bekasi increased enzyme activity has not yet occurred. ${ }^{23}$ 
Enzyme activity inside the mosquito body in the working areas of Tanjung Priok Port Health Quarantine is yet in the moderate level so that the occurring resistance level is classified as moderate resistance. Mosquitoes exposed to organophosphates could still be dead due to loss of systemic control on the nerve system of the mosquito. The test results revealed resistant status to malathion and susceptible status to temephos. The contrast occurs as the nerve impulse transmission in $A e$. aegypti is mediated by acetylcholine acting as neurotransmitters. Mechanism of action of acetylcholine is influenced by the enzyme acetyl cholinesterase; thereby hydrolyze acetylcholine into choline and acetic acid to stop the nerve impulses. ${ }^{15}$

The high level of esterase enzyme may be associated with the development of resistance. ${ }^{20}$ Increased level of esterase in mosquito is the primary mechanism of resistance to organophosphates. Such resistance may as well occur because insecticides interact first with esterase, rather than with the target sites. Sufficient amount of esterase will cause more effective hydrolysis of insecticida. ${ }^{24}$ Increased non-specific esterase enzyme is one of important issues in insecticida detoxification, as this causes the target insects become resistant (decrease in susceptibility status). ${ }^{25}$

The results obtained from the PCR process through the sequencing analysis for primers of AaSCF1 and AaSCR4 revealed the mutation in the target 989 and 1016. The results of sequencing analysis showed that there was amino acid change on the 989 sites from Serine (TCC) into Proline (CCC), whereas on 1016 site the change occurred from Valin (GTA) into Glycine (GGA). Target point 1534 on the sequencing analysis showed absence of mutation.

VGSC gene mutations at the 1534 site have not been taken place in Palembang and in Cayman Islands. ${ }^{26},{ }^{27}$ Mutation on the sites S989P, V1016G and F1534C have occurred in Myanmar and Thailand. ${ }^{19,28}$ V1016G mutation is most commonly found in Southeast Asian countries, while mutations of Ae. aegypti mosquitoes in the F1534C site have ever been reported in Pakistan.

Gene mutations occurring in the working areas of Tanjung Priok Port Health Quarantine on sites 1016 and 989 allow the possibility of pyrethroid resistance between the mutation sites. S989P mutation is often associated with V1016G mutation, yet occasionally the appearance of V1016G mutation is reported without being followed by S989P mutation. High frequency of V1016G and S989P mutations may increase the resistance level of Ae. aegypti to deltamethrin. Determination of S989P mutation effect to the pyrethroid class of insecticides could not be ascertained. ${ }^{29}$ The occurrence of V1016G mutation is not synergistic with the S989P mutation, nevertheless the S989P mutation will be followed by V1016G mutation in mosquitoes resistant to pyrethroids. ${ }^{25}$

\section{CONCLUSIONS}

Aedes aegypti mosquitoes in Tanjung Priok Port Health Quarantine working area showed resistance to malathion and cypermethrin, and are still susceptible to temephos in 2016. Moderate resistance due to an increase in non-specific esterase enzyme activities has been observed. Voltage-gated sodium channel (VGSC) gene mutation is observed on sites S989P and V1016G, while site F1534 showed absence of mutation.

\section{RECOMMENDATIONS}

Rotation of insecticida use is required to put a stop to selection pressure lasted for years. Monitoring program should be done and be evaluated on a continuing basic along with entomological surveillance data. Evaluation of insecticides could be useful to determine mosquito vector control measures accordingly.

\section{ACKNOWLEDGEMENT}

Deepest gratitude is directed towards the Port Health Quarantine in Tanjung Priok, supervisors, and all related individuals supporting the research. 


\section{REFERENCES}

1. Lederberg J, Davis JR. Emerging infectious disease from the global to the local perpective: a summary of a workshop of the forum on emerging infectious. Washington: Institute of Medicine (US) Forum on Emerging Infections; 2001. Available from: https://www.ncbi.nlm.nih.gov/pubmed/22896 870.

2. Kemenkes RI. Organisasi dan tata kerja Kantor Kesehatan Pelabuhan. Jakarta: Peraturan Menteri Kesehatan Republik Indonesia Nomor: 2348/Menkes/Per/XI/2011; 2011.

3. Departemen Kesehatan. Petunjuk teknis disinfeksi kapal laut dan pesawat udara. Dirjen PP\&PL; 2007.

4. WHO. Vector surveillance and control at ports, airpots, and ground crossing. control of neglected tropical diseases vector ecology and management capacity, alert and response supprot for International Health Regulations Capacity Development Ports, Airports and Ground Crossing.Jenewa; 2016.

5. Nusa R, Ipa M, Delia. T, Maltia. S. Penentuan status resistensi Ae. aegypti dari endemis DBD di Kota Depok terhadap malathion. Buletin Penelitian Kesehatan. 2008;36(1):20-5.

6. Widiarti. Status kerentanan Anopheles aconitus terhadap insektisida organophosfat (fenitrothion) dan karbamat (bendiocarb) di Kabupaten Jepara dengan uji biokemis. Tesis. Yogyakarta: UGM; 2000.

7. Francis S, Saavedra Rodriguez K, Perera R, Paine M, Black WC, Delgoda R. Insecticide resistance to permethrin and malathion and associated mechanisms in Aedes aegypti mosquitoes from St. Andrew Jamaica. PLoS One. 2017;12(6):1-13. doi: 10.1371/journal.pone.0179673.t001.

8. Ahmad I, Astari S, Rahayu R, Hariani N. Status kerentanan Aedes aegypti (Diptera : Culicidae) pada tahun 2006-2007 terhadap malation di Bandung, Jakarta, Surabaya, Palembang dan Palu. Biosfera. 2009;26(2):85-9. doi: 10.20884/1.mib.2009.26.2.119.

9. WHO. Test procedures for insecticide resistance monitoring in malaria mosquitoes. Jenewa: Wolrd Health Organization; 2016.
10. Caroline C. Insecticide fact sheet malathion. asdfghjkl;'

11. Journal of Pesticide Reform. 2003;23(4):10-5. Available from: https://d3n8a8pro7vhmx.cloudfront.net/ncap/p ages/26/attachments/original/1428423398/mal athion.pdf?1428423398.

12. Sunaryo, Ikawati B, Rahmawati, Widiastuti D. Status resistensi vektor demam berdarah dengue (Aedes aegypti) terhadap malathion $0,8 \%$ dan permethrin $0,25 \%$ di Provinsi Jawa Tengah. Jurnal Ekologi Kesehatan. 2014;13(2):146-52.

13. Widiastuti D, Ikawati B. Resistensi Malathion dan aktivitas enzim esterase pada populasi nyamuk Aedes aegypti di Kabupaten Pekalongan. BALABA. 2016;12(2):61-70. doi: 10.22435/blb.vI2i2.199.

14. Auteri M, Francesco LR, Blanda V, Torina A. Insecticide resistance associated with KDR mutation in Aedes albopictus: an update on worldwide evidances. Hindawi. 2018; Article ID 3098575:1-10. doi: $10.1155 / 2018 / 3098575$.

15. Lidia K, Levina E, Setianingrum S. Deteksi dini resistensi nyamuk Aedes albopictus terhadap insektisida organofosfat di daerah endemis demam berdarah dengue di Palu. Majalah Kesehatan Masyarakat. 2018;3(2):106-10.

16. Brengues C, Hawkes NJ, Chandre F, Mc Carroll L, Duchon S, Guillet $\mathrm{P}$, et al. Pyrethroid and DDT cross-resistance in Aedes aegypti is correlated with novel mutations in the voltage-gated sodium channel. Medical and Veterinary Entomol. 2003;17(1):87-94. doi: 10.1046/j.1365-2915.2003.00412.x.

17. Lima JB, Da-Cunha MP, Da Silva RC, Galardo AK, Soares SS, Braga IA, et al. Resistance of Aedes aegypti to organophosphates in several municipalities in the state of Rio de Janeiro and Espírito Santo Brazil. The American Journal of Tropical Medicine and Hygiene. 2003;68(3):329-33. Available from: https://www.ncbi.nlm.nih.gov/pubmed/12685 640.

18. WHO. Insecticide resistance technical update. entomology and vector control unit. Jenewa: World Health Organization; 2016. 
19. Lee HL, Rapid and simple biochemical method fot the detection of insecticide resistance due to elevate esterase activity in Culex quinquefasciatus. Tropical Biomedicine. 1990;7(1):21-8. Available from: https://www.cabdirect.org/cabdirect/abstract/1 9912079985.

20. Widiarti. Uji mikroplat aktivitas enzim esterase untuk mendeteksi resistensi Anopheles aconitus terhadap insektisida malation. Jurnal Kedokteran YARSI. 2015;13(1):1-10.

21. Soenjono SJ, Suwarja, Pandean MM. Status resistensi vektor demam berdarah dengue Aedes aegypti di Kota Tomohon. Jurnal Vektor Penyakit. 2017;11(2):43-8. doi: 10.22435/vektorp.v11i2.6470.43-48.

22. Satoto TBT, Alvira N, Wibawa T, Dibtyanusa A. Controlling factors that potentially against transmission of dengue hemorrhagic fever at state elementary schools in Yogyakarta. Kesmas: National Public Health Journal. 2017;11(4):178-84. 10.21109/kesmas.v11i4.1248.

23. WHO. Monitoring of insecticide resistance in malaria vectors. Jenewa: World Health Organization; 1980.

24. Shinta, Sukowati S, Fauziah A. Kerentanan nyamuk Ae. aegypti di Daerah Khusus Ibu Kota Jakarta dan Bogor terhadap insektisida malathion dan lambdacyhalotrin. Jurnal Ekologi Kesehatan. 2008;7(1):722-31.

25. Peiris HTR, Hemingway J. Characterisation and inheritance of elevated esterase in organophosphorus and carbamate insecticide resistant Culex quinquefasciatus (Diptera : Culicidae) from Sri Langka. Bulletin of Entomological Research. 1993;83(1):127-32. Available from: https://www.cambridge.org/core/journals/bull etin-of-entomologicalresearch/article/characterization-andinheritance-of-elevated-esterases-inorganophosphorus-and-carbamate-insecticideresistant-culex-quinquefasciatus-dipteraculicidae-from-srilanka/DFDD840520C059C3A074A48665E84 E8D.
26. Stenhouse SA, Plernsub S, Yanola J, Lumjuan N, Danrakool A, Choochote W, et al. Detection of the V1016G mutation in the voltage-gated sodium channel gene of Aedes aegypti (Diptera: Culicidae) by allele-specific PCR assay, and its distribution and effect on deltamethrin resistance in Thailand. Parasit Vectors. 2013;6(1):253. doi: 10.1186/17563305-6-253.

27. $\mathrm{K}$ Y. Role of detoxification esterase in insecticide resistances. New York: Pest Resistance to Pesticide. Plenum Press; 1976.

28. Yanola J, Pradya S, Catherine W, Woottichai N, La-aied P. A Novel F1552/C1552 point mutation in the Aedes aegypti voltage-gated sodium channel gene associated with permethrin resistance. Pesticide Biochemistry and Physiology. 2010;96(3):127-31. doi: 10.1016/j.pestbp.2009.10.005.

29. Saelim, V, Brogdon WG, Rojanapremsuk J, Suvannadabba S, Pandii W, Jones JW, et al.. Bottle and biochemical assay on temefos resistence in Aedes aegypti in Thailand. Southeast Asian J Trop Med Public Health. 2005;36(2):417-25. Available from: https://www.ncbi.nlm.nih.gov/pubmed/15916 049

30. Haris AF, Rajatileka S, Ranson H. Pyrethroid resistance in Aedes aegypti from Grand Cayman. American Jounal of Tropical Medicine and Hygiene. 2010;83(2):277-84. doi: 10.4269/ajtmh.2010.09-0623. 